\title{
Pollution or Protection - What Early Survey Data Shows on Rapid Waterbird Utilisation of a Newly Established Sewage Treatment Plant in Urban Ghana, West Africa?
}

\section{Lars Haubye Holbech ( $\square$ l.holbech@gmail.com )}

University of Ghana https://orcid.org/0000-0002-9975-7825

Cara Caroline Cobbinah

University of Ghana College of Basic and Applied Sciences

\section{Research Article}

Keywords: aquatic birds, abundance, constructed wetland, distribution, diversity, utilisation

Posted Date: April 13th, 2021

DOl: https://doi.org/10.21203/rs.3.rs-408769/v1

License: (a) (1) This work is licensed under a Creative Commons Attribution 4.0 International License.

Read Full License

Version of Record: A version of this preprint was published at Wetlands on November 12th, 2021. See the published version at https://doi.org/10.1007/s13157-021-01510-w. 


\section{Abstract}

Heavy urbanisation increasingly isolates and exerts pressure on natural wetlands, particularly in rapidly growing tropical developing countries, including West Africa. Constructed wetlands such as sewage treatment plants, may unintendedly offer wildlife protection due to prohibitive access control and limited use, thereby attracting wary and specialised waterbirds, otherwise heavily disturbed in formally protected wetlands with less polluted waterbodies. We present data from a rapid survey on 1-year post-opening colonisation and use of waterbirds in a recently constructed 11 ha restricted-access sewage treatment plant situated in Ghana's capital, Accra. During November-December 2013 and January 2014, nine daily counts in each month produced an accumulated count of $>4200$ observations belonging to 26 species of waterbirds, including several important Afro-Palaearctic and intra-African migrants, hereunder ardeids, piscivorous divers, waterfowl and waders. The distributional patterns of waterbirds clearly reflected local foraging opportunities and water quality parameters in the system of 12 inter-connected waste stabilisation ponds. A nearby semi-natural wetland with cleaner waterbodies, but higher levels of human interference, supported half as many waterbirds, predominantly commensal gregarious species. Our data suggests that strict protection from disturbances outweighs possible negative implications attributed to mere pollution of waterbodies supporting various waterbird guilds, thus highlighting the potential importance of non-formally protected sewage treatment plants distributed in functional networks, as a complement to designated wetlands. We contemplate that establishing similar or larger plants jointly will improve sewage treatment and waterbird conservation in urban Ghana, and West Africa in general.

\section{Introduction}

Wetlands are high on the conservation agenda across the globe due to unsustainable exploitation and degradation, driven by decades of increasing anthropogenic activities (e.g. Dudgeon et al. 2006, Keddy et al. 2009; Davidson 2014). Wetlands are subject to heavy disturbance regimes, particularly in urban areas, where draining for agriculture, farming, fishing, hunting, livestock rearing, mining, and pollution from sewage encroach upon and degrade waterbodies with associated wildlife (e.g. Schuyt 2005, Verhoeven et al. 2006; Junk et al. 2013). Among vulnerable wetland fauna are various guilds of waterbirds, including many migrants (Okes et al. 2008; Sutherland et al. 2012; Runge et al. 2015). Conservation efforts to safeguard wetlands include regulations and protection of key sites (Beatty et al. 2014; Kleijn et al. 2014), but such efforts are often hampered by increasing human population and associated economic growth, as well as inadequate management, legislation and law enforcement (O'Connell 2000; Aynalem and Bekele 2008; Gbogbo 2007a; Gbogbo et al. 2008; 2009). Scenarios of insufficient wetland conservation are particularly evident in densely populated developing countries, also in sub-Saharan Africa, including Ghana (Adams 1993; Uluocha and Okeke 2004; Gbogbo 2007b; Mitchell 2013; Vickery et al. 2014).

Formally protected wetlands in Africa, including Ramsar sites, are increasingly subject to overexploitation and illegal activities (Schuyt 2005; Gbogbo et al. 2008; Finlayson 2012; Junk et al. 2013; Lamptey and Ofori-Danson 2014). Waterbirds and their habitats are often threatened by illegal and unsustainable utilisation of natural resources, including fish stock, invertebrates and fuel wood (O'Connell 
2000; Willoughby et al. 2001; Gbogbo et al. 2008; Okes et al. 2008). Alongside unsustainable resource extraction that interferes with waterbird foraging and nesting ecology, the avifauna is also indirectly affected by water pollution and draining, as well as directly from hunting, water sports and other recreational activities (O'Connell 2000; Uluocha and Okeke 2004; Mitchell 2013). Thus, non-formally protected or unmanaged wetlands serve as important habitat supplements and sometimes alternative refuges for waterbirds (Attuquayefio and Gbogbo 2001; Gbogbo 2007b; Harebottle et al. 2008; Gbogbo and Attuquayefio 2010; Murray and Hamilton 2010). Such artificial or constructed wetlands (CW) include agro- and aquaculture ponds, irrigation dams, salt ponds, drainage canals (Froneman et al. 2001; Otieno et al. 2015), as well as sewage treatment plants (STP) of various types (Scholz and Lee 2005; Wang et al. 2014). STPs are steadily expanding in many parts of the temperate zone (Scholz and Lee 2005), subtropics (Hsu et al. 2011; Wang et al. 2016; Giosa et al. 2018) and tropics (Murray and Hamilton 2010; Murray et al. 2012, 2014), including a gradual increase in some parts of Africa (Ashkenazi 2001; Kivaisi 2001; Harebottle et al. 2008; Wang et al. 2014). Even though waterbird diversity of CWs and STPs may be inferior to designated protected areas such as Ramsar sites (Hamdi and Ismail-Hamdi 2014; Kleijn et al. 2014), substantial evidence suggests that man-made wetlands increasingly may contribute to waterbird conservation in the near future (Murray and Hamilton 2010; Wang et al. 2016). As such, although often comparatively small, isolated and situated far from other larger protected wetlands, artificial wetland habitats increasingly serve as replacement or complementary refuges for lost or degraded natural wetland biota, including vulnerable waterbird guilds (Afdhal et al. 2012; Murray et al. 2012; Giosa et al. 2018). The efficiency and success of STPs for waterbird conservation, however, depend on the degree and extent of applied ecology-based management practises and access control (Ashkenazi 2001; Hsu et al. 2011; Murray et al. 2014; Wang et al. 2016).

Majority of African studies that assess waterbird diversity and habitat utilisation in STPs are from the southern and eastern regions of the continent, with apparently limited information from the northern, western and central portions (Ashkenazi 2001; Harebottle et al. 2008; Harrison et al. 2010; Wang et al. 2014). Moreover, few studies from Africa document the early phases of STP waterbird colonisation (Ashkenazi 2001), just as most data collected are from coastal areas (Harrison et al. 2010) or inland plants, integrated with natural wetlands (Harebottle et al. 2008). Ghana, and Accra in particular, has in the past decade initiated new strategies for improved sewage treatment to curb the heavy pollution that threatens many waterbodies in the urban coastal zone (Nixon et al. 2007). Since the early 2000s, this has resulted in the planning and initial construction of improved sewage systems and different types of STPs, one of which is the Legon Sewage Treatment Plant (hereafter called LSTP) situated amidst a densely populated area in the Accra metropolis, being part of the Accra Sewerage Improvement Project (ASIP). We present data on the early-phase ( 1 year) colonisation by waterbirds at the LSTP, with emphasis on spatio-temporal abundance, distribution and diversity within various components of the plant. Our major objectives of this baseline study of a unique inland STP in urban Ghana, were to describe and assess the waterbird fauna with regards to the: 1) early inflow and colonisation; 2) spatio-temporal patterns of distribution and diversity; 3 ) relative conservation importance of migrants and rarities; 4 ) protection potential for vulnerable and wary species; 5 ) relative importance of water pollution versus unintended bird 
protection. We therefore aimed at increasing the general knowledge base on waterbird utilisation of CWs in urban landscapes of West Africa. Our early data also serve to evaluate the conservation potentials of newly established STPs, as well as highlighting the urgent need for additional and complementary refuges for vulnerable waterbirds, alongside improved sewage management in the West African subregion.

\section{Methods}

Study area

The LSTP (GPS: $5^{\circ} 39^{\prime} 50 \mathrm{~N} ; 0^{\circ} 11^{\prime} 31 \mathrm{~W}$ ) is situated $\sim 14 \mathrm{~km}$ north of the Accra coastline on a gentle slope ( $25 \mathrm{~m}$ total elevation gradient) adjacent to the main University of Ghana, Legon (UGL) campus (Fig. 1). It is bordered by the heavily-trafficated Haatso-Atomic road, thickets and farmlands surrounding the UGL campus, as well as the Legon Botanical Gardens with the integrated $>60$ yrs old constructed Vaughan's Dam, isolated from, but situated $<200 \mathrm{~m}$ away from the LSTP. This nearby $<2$ ha semi-natural wetland area comprises $\sim 1$ ha of open waterbodies bordered by narrow verges of mixed swampy vegetation zones with dense reed beds, herbs and thickets (Fig. 1), in which the avifauna was well-known $>10$ years prior to the survey (L.H. Holbech pers. obs.). The LSTP measures $\sim 11$ ha $(\sim 310 \times 360 \mathrm{~m})$, of which $\sim 6$ ha are open water in the form of ponds lined by rocky banks, and access is restricted by $2.5 \mathrm{~m}$ tall barbed wire fencing. It is a stabilization pond system (Wang et al. 2014), constructed in 2010-2012 by an African Development Bank project, and managed by the Accra Metropolitan Assembly under the ASIP. It consists of 12 ponds, with four levels of three similar-sized ponds each (Figs. 1 and 2). The four levels are inter-connected from upper level $A$ to lower level $D$ as: $A_{1-3}=$ anaerobic ponds, $5 \mathrm{~m}$ deep, measuring $\sim 60 \times 40 \mathrm{~m} ; \mathrm{B}_{1-3}=$ facultative ponds, $2.5 \mathrm{~m}$ deep, measuring $\sim 75 \times 100 \mathrm{~m} ; \mathrm{C}_{1-3}=$ upper maturation ponds, $1.3 \mathrm{~m}$ deep, measuring $\sim 85 \times 75 \mathrm{~m} ; \mathrm{D}_{1-3}=$ lower maturation ponds, $1.3 \mathrm{~m}$ deep, measuring $85 \times 65 \mathrm{~m}$ (Fig. 1). Water flow is gravitational, with a maximum daily inlet capacity of $\sim 9,000 \mathrm{~m}^{3}$, receiving water from the campuses of UGL, Presbyterian Boys' Secondary School, and other surrounding stateowned institutions. The small anaerobic ponds are lined with a rubber membrane and flanked by three parallel concrete water-inlet ducts, measuring $\sim 0.9 \mathrm{~m}$ wide and $\sim 0.9 \mathrm{~m}$ deep (Figs. 1 and 2); these ponds were half covered with sludge at the time of our study, and fill up in about 5 years. The large facultative ponds are lined with granite rocks of $\sim 0.1-0.5 \mathrm{~m}$ diameter, each having a $\sim 1.3 \mathrm{~m}$ wide rock intercept situated perpendicularly midway to reach halfway shore to shore (Figs. 1 and 2). The two similar three-set maturation ponds are likewise lined with granite rocks, but lack midway intercepts. At the time of our study, the granite rock linings were partially covered by grasses, herbs and shrubs, typically White popinac Leucaena leucocephala, Bachelor's button Gomphrena celosioides, Hogweed Boerhavia diffusa, Hornbeam-leaved crossberry Grewia carpinifolia, whereas the surroundings were dominated by 1-2 m tall and tough grasses such as Guinea grass Panicum maximum, partly covering the laterite gravels. The vegetation lining the ponds, as well as floating and submerged macrophytes both of which, was regularly controlled mechanically or by Glyphosate herbicide application. Floating or submerged macrophytes were only present in the $\mathrm{C}$ and D ponds; D2 was particularly extensively covered by water lilies (Nymphaea sp.) 
and reeds (Typha sp.) at the edges. Water clarity was least in the B and C facultative/maturation ponds, indicating explosive algal growth. The LSTP is the largest wetland in a radius of $\sim 10 \mathrm{~km}$ from the UGL campus, with the nearest other large constructed wetland $\sim 9 \mathrm{~km}$ to the east, namely the $\sim 1.4 \mathrm{~km}^{2}$ Nungua Agriculture Station Dam with its associated marshy areas around the Ayensu River. The Sakumo Lagoon, a Ramsar Site of $\sim 13 \mathrm{~km}^{2}$ which joins the Ashaiman Agricultural Dam, is situated $\sim 17 \mathrm{~km}$ to the south-east (Fig. 1).

\section{Data Collection}

Nine systematic daily bird counts per month were conducted by two observers from November 2013 to January 2014, a period that coincides with the peak numbers of Afro-Palaearctic waterbird migrants in Ghana (Ntiamoa-Baidu 1991; Lamptey and Ofori-Danson 2014). Given the likelihood that the abundance of some species fluctuated throughout the day, three separate count periods were applied equally on the nine different census days per month, thus three counts each in morning (06h00-08h00), midday (12h0014h00), and late afternoon (16h00-18h00). We anticipated that this systematic sampling of three time periods replicated thrice in each month increased the probability of recording as many species as possible, as well as reflecting the true spatio-temporal abundance at the plant. Each of the three replicate ponds $(1-3)$ at each level (A-D) was counted as a unit, before moving on to the next pond, starting from either $A_{1}$ or $D_{3}$ (Fig. 1) on each day, on a day-wise rotational basis. Total counts in each of the 12 ponds were done from vantage points with good visibility and aided by a pair of $10 \times 42$ binoculars, and occasionally a telescope (20-60x). Care was taken to avoid repeat-counting individuals that moved from pond to pond, particularly for wary and mobile species such as ducks and other gregarious birds. This was done by constantly observing the movements of flushed individuals when cautiously approaching a pond. Ponds A-C could comfortably be surveyed and monitored in this way, whereas ponds $D$ were not visible from the levels of ponds $A$ and $B$. Most flocks relocated from only one level to the adjacent, and rarely did so more than two levels apart. In the case of large numbers of White-faced Whistling Duck Dendrocygna viduata and other gregarious birds, recounting several times with subtractions and additions or averaging were often deemed necessary; counts of such species were associated with an error of $\sim 10 \%$. Notes of breeding were taken on nests, eggs, juvenile or immature birds.

Besides bird counting, sampling of physico-chemical water quality parameters in each pond was undertaken on a single day in December 2013, including pH, turbidity (NTU) and total dissolved oxygen (TDO). These parameters could then be related to abundance and diversity of birds in order to evaluate any apparent implications for the waterbirds present at the four levels (A-D). Other vertebrates, invertebrates and characteristic plants observed were also recorded opportunistically.

\section{Data Analysis}

The three similar ponds at each level were regarded as replicate units in calculating monthly means \pm SD of bird abundance based on counts at all four pond levels over the three-month study period. We used the exponential of the Shannon-Wiener species diversity index $\left(\mathrm{ExpH}^{\prime}\right)$ to calculate total effective species 
number (Jost 2006) for each pond level based on the three replicate counts for each level over the entire study period. Similarly, we used the Morisita-Horn index $\left(\mathrm{C}_{H}\right)$ to assess the overall species similarity among the four pond levels. As such, we were able to assess the spatio-temporal abundance, diversity and similarity of waterbirds distributed at the LSTP. Likewise, for the water quality parameters, the mean \pm SD was calculated based on the replicate ponds (1-3) at each of the four levels. Each species was classified into six overall foraging guilds based on information in Ntiamoa-Baidu et al. (1998), as: Guild 1 = Herbivorous waterfowl (ducks); Guild 2 = Visual surface foraging waders; Guild 3 = Tactile surface foraging waders; Guild 4 = Pelagic foraging waders; Guild 5 = Stalking herons; Guild 6 = Diving waterfowl (grebes and cormorants). Based on this classification, the modes of foraging employed by species with their respective abundances could be compared, in order to assess the habitat and niche provisions provided for by the four levels (ponds A-D). Such assessment is important for understanding the spatial distribution of birds in various types of STPs, and this information can be used to optimize construction design and management practises in order to increase waterbird protection and conservation. Each species was also classified according to migratory status as Afro-Palaearctic migrant, intra-African migrant, and resident for Ghana (Dowsett-Lemaire and Dowsett 2014), as well as global conservation status following the IUCN Red List criteria (Handbook of the Birds of the World Alive/BirdLife, online data).

\section{Results}

Total abundance of birds in relation to pond levels

We accumulated a total of 4224 bird observations counted on 27 days over the three-month study period, translating into a mean of 156 birds per day-count (Table 1). The six most abundant species comprised $\sim 82 \%$ of individual birds counted, and were in the following order of descending dominance; White-faced Whistling Duck ( 20\%), Cattle Egret Bubulcus ibis ( 17\%), Common Sandpiper Actitis hypoleucos ( 14\%), Black-winged Stilt Himantopus himantopus ( 13\%), Wood Sandpiper Tringa glareola $(\sim 11 \%)$ and Spur-winged Lapwing Vanellus spinosus ( 7\%). Other common species were Little Grebe Tachybaptus ruficollis ( 4\%), Common Greenshank Tringa nebularia (3\%) and Senegal Thick-knee Burhinus senegalensis (3\%). Abundance was significantly lower at A ponds $\left(\chi^{2}=526.3, p<0.00001, d f=3\right)$, and 45 times higher at $B, C$ and $D$ ponds, amongst which abundance did not differ significantly $\left(\chi^{2}<1.3, p>\right.$ $0.5, \mathrm{df}=2)$. The most abundant birds at A ponds were Common Sandpiper, Black-winged Stilt, Spurwinged Lapwing and Wood Sandpiper, with a few other waders. Similarly, at B ponds, common and wood sandpipers dominated together with black-winged stilts, spur-winged lapwings, as well as Senegal thickknees, common greenshanks and cattle egrets (Table 1). The $C$ and $D$ ponds differed from $A$ and $B$, having a dominance of particularly White-faced Whistling Duck, as well as relatively higher numbers of cattle egrets and little grebes. Although $C$ and $D$ ponds were very similar, $C$ had particularly high dominance of white-faced whistling ducks, whereas cattle egrets dominated at D (Table 1). Total monthly counts from November 2013 to January 2014 were 1463, 1164 and 1597, respectively. These overall abundances were significantly different $\left(\chi^{2}=36.3, p<0.00001, d f=2\right)$, indicating stable populations 
during the study period, but a relatively lower abundance in December, attributed primarily to lower abundance for the three most abundant species; White-faced Whistling Duck, Cattle Egret and Common Sandpiper (Table 1). The daily count periods of morning-midday-afternoon did not show any significant differences indicating stable populations throughout the daytime hours. White-faced whistling ducks displayed highest daily and monthly abundance fluctuations during the study period, and were often flight-active at early-late evening and night.

Species richness, diversity and similarity in relation to pond levels

We recorded a total of 26 waterbird species during the three-month study period, including 11 waders, eight ardeids, six waterfowl and the Malachite Kingfisher Corythornis cristatus (Table 1). Only seven species were detected at A ponds, which contrasted with 19 or 20 at B, C and D ponds. Species diversity was highest at $C$ ponds, whereas it was very similar at $B$ and $D$ ponds (Table 1 ). The distinctively higher species diversity at $C$ ponds is attributable to a higher evenness and lower dominance of the most abundant species (Table 1). Likewise, species similarity was highest between $A$ and $B$ ponds, with $>86 \%$ shared species, whereas $C$ and $D$ ponds had $\sim 60 \%$ shared species (Table 2 ). In contrast, D ponds versus $A$ and $B$ ponds, respectively, displayed low similarities of $15-20 \%$ shared species. $C$ ponds versus $A$ and B ponds, respectively, had medium similarity of $\sim 31-32 \%$ (Table 2 ).

Distribution of foraging guilds in relation to pond levels

The White-faced Whistling Duck (Guild 1) was absent from A ponds, scarce at B ponds, fairly abundant at $D$ ponds, and most abundant at $C$ ponds (Table 3). Only two other species in Guild 1 were observed; the Common Moorhen Gallinula chloropus, exclusively and equally found in $\mathrm{C}$ and $\mathrm{D}$ ponds, and a single Knob-billed Duck Sarkidiornis melanotos in January 2014 at B ponds (Table 1). Visual surface foraging waders (Guild 2) as the most diverse foraging guild with nine species, was represented at all levels, but with highest abundance and diversity at B ponds, a pattern similarly displayed by the two very abundant small sandpipers (Tables 1 and 3). Only one tactile surface foraging species (Guild 3), Little Stint Calidris minuta, was detected, indicating the lack of exposed mud flats during the study period. In contrast, the pelagic foraging waders (Guild 4), notably represented by black-winged stilts, showed high affiliation to $B$ and $C$ ponds, moderate for A ponds, and only occasional at D ponds. The very diverse guild of eight piscivorous stalking ardeids (Guild 5), showed outstandingly high diversity and abundance at respectively $C$ and $D$ ponds (7-8 species), the latter dominated by large cattle egret flocks. This guild, however, was not recorded at A ponds. Similarly, the guild of diving piscivores (Guild 6), represented primarily by the Long-tailed Cormorant Microcarbo africanus and Little Grebe, showed highest affinity for $C$ and $D$ ponds, with a few of the latter species at B ponds, and a complete absence of the guild at A ponds.

Migratory and conservation status of waterbirds

We recorded a total of 11 Afro-Palaearctic migrants ( $42 \%$ of overall species richness), including Blackwinged Stilt, whose migration status remains uncertain in Ghana (Dowsett-Lemaire and Dowsett 2014). Resident breeders numbered at most 17 species ( 65\%) including Little Egret Egretta garzetta and 
Intermediate Egret Ardea intermedia, both with uncertain breeding status in Ghana (Dowsett-Lemaire and Dowsett 2014). Four species were intra-African migrants, including Intermediate Egret. Overall, the proportions of resident breeders therefore seemed higher than migrants. Even amongst migrants, AfroPalaearctics were in the majority. All species recorded had IUCN Red List status as 'Least Concern', and except for Knob-billed Duck, all species are commonly recorded in coastal habitats of Ghana (NtiamoaBaidu 1991; Lamptey and Ofori-Danson 2014).

Water quality in relation to pond levels

Levels of $\mathrm{pH}$ showed weak to moderate alkalinity, and there was significant differences among the four pond levels (Kruskal-Wallis H-test $=9.359, \mathrm{p}=0.02488, \mathrm{df}=3$ ), with $\mathrm{A}$ ponds lowest, $\mathrm{C}$ ponds highest, and $B$ and D ponds similar (Fisher's LSD test) (Table 3 ). Total dissolved oxygen (TDO) showed significant differences across the pond levels (Kruskal-Wallis H-test $=8.128, p=0.04344, \mathrm{df}=3$ ), with $\mathrm{C}$ ponds higher than both $A$ and $D$ ponds, whereas $B$ and $C$ ponds, as well as $A, B$ and $D$ ponds were similar (Fisher's LSD test). Turbidity also varied significantly among the four levels (Kruskal-Wallis H-test $=8.744, p=0.0329$, $d f=3$ ), with $D$ ponds significantly lower than $A, B$ and $C$ ponds. However, turbidity levels in the three latter ponds were not significantly different (Fisher's LSD test). In summary, ponds B and C showed highest levels of both TDO and turbidity, indicating highest levels of algal growth, whereas the anaerobic nature of A ponds was evidenced by very low TDO and moderately high turbidity. The D ponds had much lower turbidity and relatively low TDO, indicating lower algal densities.

\section{Discussion}

Distributional patterns of waterbirds at the LSTP

The LSTP waterbird fauna was represented by six separate foraging guilds, two of which dominated in terms of both species number and abundance, namely visual surface waders (Guild 2) and stalking ardeids (Guild 5), in addition to two non-diverse but abundant guilds, herbivorous waterfowl (Guild 1) and pelagic foraging waders (Guild 4). This guild pattern, with relatively low abundance of diving piscivores (Guild 6) and tactile foraging waders (Guild 3 ) suggests that turbidity was excessively high and/or that prey availability was limited in water columns and on exposed mudflats. The university community and its co-users of the LSTP went on vacation during the months of December and January, causing the facility to run at low capacity. It was only during this period of low water levels at ponds $C$ and $D$, that foraging conditions were favourable to Guild 3 , which included little stints. Particularly ponds $C$ and $D$ with the highest water clarity supported ardeids, cormorants, grebes and kingfishers. At the time of the study, it was unlikely that fishes may have been introduced by natural means from the nearby Vaughan's Dam, although pelagic invertebrates that constitute major food sources for pursuit-diving little grebes may have been abundant (Santoul and Mastrorillo 2004). Likewise, the few long-tailed cormorants suggested that although these were attracted to the ponds, successful prey captures were most likely large invertebrates (Otieno et al. 2015). Although it is possible that particular pelagic invertebrates (e.g. predaceous diving beetles, Dysticidae) were most abundant in the $B$ and $C$ ponds, low water transparency 
here may have limited actual prey availability for both diving and darting foragers, as compared to the significantly less turbid D ponds. In summary, the distribution of waterbirds at LSTP largely followed the ecological requirements for each of the six foraging guilds, thus probably reflecting a compromise between prey abundance and availability versus water level (Ntiamoa-Baidu et al. 1998; Gbogbo et al. 2009) and clarity (Holbech et al. 2018), the latter related to nutrient concentrations and algal blooms (Lamptey and Ofori-Danson 2014).

Significance and potential implications of LSTP data for waterbird conservation in urban Ghana

This study was conducted $\sim 1$ year post-opening of the sewage inlet, October 2012, and documented at least 26 waterbird species with average day-counts of $\sim 160$ birds, and occasionally up to $>220$ birds. Notable abundant species were White-faced Whistling Duck (up to 50-100 at a time), Common Sandpiper, Black-winged Stilt, Wood Sandpiper, Spur-winged Lapwing, Little Grebe, Common Greenshank and Senegal Thick-knee. Although not completely comparable with regards to size and structure of the LSTP, it is notable that the nearby Vaughan's Dam, with superior water quality and clarity, only supported 10-15 regularly recorded waterbird species, up to and during the same study period, particularly gregarious, commensal and least wary species, such as Cattle Egret, Long-tailed Cormorant, Squacco Heron Ardeola ralloides and Black-crowned Night Heron Nycticorax nycticorax. Since 2012-2013, Vaughan's Dam has been subject to intensification of commercial recreational activities, thus rapidly reducing numbers of wary waterfowl and wader species, hereunder sandpipers, lapwings, moorhens and jacanas, with a complete absence of ducks and little grebes. This semi-natural wetland, both with a higher aesthetic value and better water quality, thus supported far fewer waterbirds than the 'repugnant' LSTP, hence most likely attributed to its small size combined with the much higher anthropogenic disturbance levels.

The relatively small LSTP pond-bank-verges area ( $\sim \mathrm{ha})$ implies that the overall average bird abundances translates into a mean density of $\sim 27$ birds/ha, and occasionally up to $\sim 35-40$. In comparison the mean density of birds at nearby coastal wetlands, including Ramsar sites, ranges between 3-9 birds/ha (Gbogbo and Attuquayefio 2010), given their much larger areas (> $250 \mathrm{ha}$ ), such as Sakumo Lagoon (1340 ha) and Densu Delta (4620 ha). Overall bird density at LSTP was also considerably higher than those recorded for rice fields across West Africa, ranging from 4-20 birds/ha (Wymenga and Zwarts 2010) or artificial wetlands of Tunisia with $>1$ bird/ha (Hamdi and Ismail-Hamdi 2014). However, LSTP-density is similar to densities reported from a South African 53.4 ha large wastewater treatment plant of $>26$ birds/ha (Harebottle et al. 2008). The relatively high density of birds recorded at the LSTP throughout the study period, indicates that despite heavily polluted water bodies, foraging opportunities remain conducive for several waterbird guilds.

The 26 waterbird species comprised six distinctive foraging guilds that utilised water columns, banks, and associated grounds and grassland verges. Apart from favourable foraging prospects, this diverse avian assemblage witness that fence-enclosure and staff surveillance of the plant provided sufficient protection for waterbirds against various human interferences. In contrast, both formally protected 
Ramsar sites (e.g. Sakumo and Densu Delta) and unprotected coastal wetlands in the Accra Metropolis are prone to high levels of natural resource exploitation (Attuquayefio and Gbogbo 2001; Lamptey and Ofori-Danson 2014), thus negatively affecting waterbird food resources such as fish and crabs (Gbogbo et al. 2008). Furthermore, direct disturbances from hunting and other activities that distress wary species such as waterfowl have a negative impact (Gbogbo 2007b; Gbogbo et al. 2008). We therefore believe, that the combined effect of a nutrient rich and safe environment, are prime factors for the rapid waterbird colonisation at LSTP. STPs of this nature, even when located inland, may have positive implications for waterbird conservation in urban areas of Ghana and West Africa in general, notwithstanding the poor conservation status of many wetlands in densely populated regions (Attuquayefio and Gbogbo 2001; Lamptey and Ofori-Danson 2014).

The ASIP under the Accra Metropolitan Assembly initially planned for an additional similar STP adjoining the Densu Delta Ramsar site, but further constructions ceased prior to the LSTP completion. Therefore, LSTP is presently the only available waste stabilisation pond system in Accra and coastal Ghana, whilst other mechanical STPs also have been constructed. Based on the rapid colonisation, consistent and significant use of the whole plant by a diverse waterbird assemblage, we suggest that the proliferation of similar STPs in urban and peri-urban Ghana, most likely will contribute positively to waterbird conservation, as well as minimising the negative effects of sewage discharge into natural waterbodies and the sea. Likewise, monitoring and research on waterbirds and their ecology at STPs, will provide more knowledge on the conservation impacts that these artificial wetlands have in a rapidly growing West African urban coastal zone. We therefore recommend a rapid expansion of STPs in Ghana and West Africa, and highlight the importance of future monitoring and assessment of the impacts such plants have on abundance, diversity and distribution of waterbirds. State-owned lands, currently reserved for public space, green areas and other recreational sites without housing potentials, could be earmarked for STP developments, including areas adjoining governmental institutions and facilities. Additionally, focus should be on ecological implications of STPs for vulnerable species, species' susceptibility to microbial diseases, intra- and interspecific interactions including agonistic and interference competition, as well as potential for heavy metal bioaccumulation, and for zoonosis transmission. Finally, we recommend research into STP management practises that reconcile effective water treatment with habitats that support a balanced and diverse waterbird fauna.

\section{Conclusion}

We demonstrate that a relatively small constructed urban wetland situated far from the coast or other nearby large inland wetlands, was subject to rapid colonisation by a diverse assemblage of both migrant and resident waterbirds. Waterbirds benefitted from the rich food sources of invertebrates and plankton, in combination with informal protection by virtue of the restricted nature of the managed STP. We anticipate that abundance and species diversity of waterbirds will increase as the biota matures, and waterbirds habituate to this protected wetland oasis amidst an otherwise densely populated urban coastal zone of West Africa. However, the persistence of diverse bird populations at similar STPs will 
depend on careful habitat management. Future long-term studies and population monitoring that encompasses the full calendar year could decipher such interactive relationships.

\section{Declarations}

\section{Acknowledgements}

Firstly, great thanks to Mr. Alfred Ali Nuoh, Centre for African Wetlands, University of Ghana, who assisted in identification and counting of birds at the LSTP. Secondly, the Managing Director, Mr. Deo Datus Appiah, Val Terra Ltd. (Tema), in liaison with the Accra Metropolitan Assembly, for granting permit, as well as encouragement of the work. Also great thanks to an anonymous for constructive criticism and editing of the manuscript. Finally, thanks to Dr. William Gblerkpor for assistance with drone imaging at LSTP.

\section{Author contributions}

Both authors contributed to the study, and read and approved the final manuscript; LHH designed and supervised the study, participated in the initial data collection, performed the majority of data analysis, initiated the draft and prepared the final manuscript; CCC conducted the majority of data collection, and made contributions to material preparation and data analysis.

\section{Funding}

This study did not receive any funding from any source or institution.

\section{Data Availability}

The data generated or analysed during this study are included in this published article; raw Excel datasets are available from the corresponding author on reasonable request.

\section{Compliance with ethical standards}

Prior consent and permissions were obtained from respective authorities.

\section{Conflicts of interest}

The authors declare that they have no conflict of interest.

\section{References}

1. Adams WM (1993) Use of wetlands and sustainable development in West Africa. The Geogr J 159(2):209-218. https://www.jstor.org/stable/3451412

2. Afdhal B, Charfi-Cheikhrouha F, Moali A (2012) Tunisian man-made wetlands as alternative habitats for waterbirds and their role for conservation. Afr J Ecol 51:154-163. https://doi.org/10.1111/aje.12022 
3. Ashkenazi S (2001) Long-term trends in the breeding populations of waterbirds (1951-1985) at a sewage treatment plant. Ostrich 72(1-2):10-19. https://doi.org/10.2989/00306520109485277

4. Attuquayefio DK, Gbogbo F (2001) Prospects of conserving wetlands along the Mukwe Lagoon at Nungua in the Greater Accra Region of Ghana. W Afr J Appl Ecol 2:65-75. https://doi.org/10.4314/wajae.v2i1.45564

5. Aynalem S, Bekele A (2008) Species composition, relative abundance and distribution of bird fauna of riverine and wetland habitats of Infranz and Yiganda at southern tip of Lake Tana, Ethiopia. Trop Ecol 49(2):199-209. ISSN 0564-3295.

6. Beatty WS, Kesler DC, Webb EB, Raedeke AH, Naylor LW, Humburg DD (2014) The role of protected area wetlands in waterfowl habitat conservation: Implications for protected area network design. Biol Conserv 176:144-152. https://doi.org/10.1016/j.biocon.2014.05.018

7. Davidson NC (2014) How much wetland has the world lost? Long-term and recent trends in global wetland area. Mar Freshwat Res 65(10):934-941. https://doi.org/10.1071/MF14173

8. Dudgeon D, Arthington AH, Gessner MO, Kawabata Z-I, Knowler DJ, Lévêque C, Naiman RJ, PrieurRichard A-H, Soto D, Stiassny MLJ, Sullivan CA (2006) Freshwater biodiversity: importance, threats, status and conservation challenges. Biol Rev 81:163-182.

https://doi.org/10.1017/S1464793105006950

9. Finlayson CM (2012) Forty years of wetland conservation and wise use. Aquat Conserv: Marine Freshw Ecosyst 22(2): 139-143. https://doi.org/10.1002/aqc.2233

10. Froneman A, Mangnall MJ, Little RM, Crowe TM (2001) Waterbird assemblages and associated habitat characteristics of farm ponds in the Western Cape, South Africa. Biodiv Conserv 10:251-270. https://doi.org/10.1023/A:1008904421948

11. Gbogbo $F(2007 a)$ Impact of commercial salt production on wetland quality and waterbirds on coastal lagoons in Ghana. Ostrich 78(1):81-87. https://doi.org/10.2989/OSTRICH.2007.78.1.12.56

12. Gbogbo $F(2007 b)$ The importance of unmanaged coastal wetlands to waterbirds at coastal Ghana. Afr J Ecol 45:599-606. https://doi.org/10.1111/j.1365-2028.2007.00778.x

13. Gbogbo F, Oduro W, Oppong SK (2008) Nature and pattern of lagoon fisheries resource utilisation and their implications for waterbird management in coastal Ghana. Afr J Aquat Sci 33(3):211-222. https://doi.org/10.2989/AJAS.2008.33.3.3.615

14. Gbogbo F, Oduro W, Oppong SK (2009) Response of waterbird species to fluctuating water levels in tropical coastal wetlands. Afr J Ecol 48:637-643. https://doi.org/10.1111/j.1365-2028.2009.01156.x

15. Gbogbo F, Attuquayefio DK (2010) Issues arising from changes in waterbird population estimates in coastal Ghana. Bird Pop 10:79-87.

16. Giosa E, Mammides C, Zotos S (2018) The importance of artificial wetlands for birds: A case study from Cyprus. PLoS ONE 13(5):e0197286. https://doi.org/10.1371/journal.pone.0197286

17. Hamdi N, Ismail-Hamdi S (2014) Testing whether artificial wetlands as habitats for waterbirds are good alternatives to natural wetlands: a case study of dams located in Northern Tunisia. Life environm 64:47-57. ISSN 0240-8759. 
18. Harebottle DM, Williams AJ, Weiss Y, Tong GB (2008) Waterbirds at Paarl Waste Water Treatment Works, South Africa, 1994-2004: seasonality, trends and conservation importance. Ostrich 79(2): 47163. https://doi.org/10.2989/OSTRICH.2008.79.2.4.578

19. Harrison JA, Williams AJ, Maclver M (2010) Breeding site selection by colonial waterbirds given various combinations of constructed or natural alternatives over a 10-year period. Ostrich 81(3): 197203. https://doi.org/10.2989/00306525.2010.519535

20. Holbech LH, Gbogbo F, Aikins TK (2018) Abundance and prey capture success of Common Terns (Sterna hirundo) and Pied Kingfishers (Ceryle rudis) in relation to water clarity in south-east coastal Ghana. Avian Res 9:25. https://doi.org/10.1186/s40657-018-0116-7.

21. Hsu C-B, Hsieh H-L, Yang L, Wu S-H, Chang J-S, Hsiao S-C, Su H-C, Yeh C-H, Ho Y-S, Lin H-J (2011) Biodiversity of constructed wetlands for wastewater treatment. Ecolog Engin 37(10):1533-1545. https://doi.org/10.1016/j.ecoleng.2011.06.002

22. Jost L (2006) Entropy and diversity. Oikos 113(2):363-375. https://doi.org/10.1111/j.2006.00301299.14714.x

23. Junk WJ, An S, Finlayson CM, Gopal B, Květ J, Mitchell SA, Mitsch WJ, Robarts RD (2013) Current state of knowledge regarding the world's wetlands and their future under global climate change: a synthesis. Aquat Sci 75:151-167. https://doi.org/10.1007/s00027-012-0278-z

24. Keddy PA, Fraser LH, Solomeshch Al, Junk WJ, Campbell DR, Arroyo MTK, Alho CJR (2009) Wet and wonderful: The world's largest wetlands are conservation priorities. BioScience 59(1):39-51. https://doi.org/10.1525/bio.2009.59.1.8

25. Kivaisi AK (2001) The potential for constructed wetlands for wastewater treatment and reuse in developing countries: a review. Ecolog Engin 16:545-560. https://doi.org/10.1016/S09258574(00)00113-0

26. Kleijn D, Cherkaoui I, Goedhart PW, Hout J, Lammertsma D, Fuller R (2014) Waterbirds increase more rapidly in Ramsar-designated wetlands than in unprotected wetlands. J Appl Ecol 51(2):289-298. https://doi.org/10.1111/1365-2664.12193

27. Lamptey AM, Ofori-Danson PK (2014) Review of the distribution of waterbirds in two tropical coastal Ramsar lagoons in Ghana, West Africa. W Afr J Appl Ecol 22(1):77-91. https://www.ajol.info/index.php/wajae/article/view/108001 (elSSN: 0855-4307)

28. Mitchell SA (2013) The status of wetlands, threats and the predicted effect of global climate change: the situation in Sub-Saharan Africa. Aqu Sci 75:95-112. https://doi.org/10.1007/s00027-012-0259-2

29. Murray CG, Hamilton AJ (2010) Perspectives on wastewater treatment wetlands and waterbird conservation. J Appl Ecol 47:976-985. https://doi.org/10.1111/j.1365-2664.2010.01853.x

30. Murray CG, Loyn RH, Kasel S, Hepworth G, Stamation K, Hamilton AJ (2012) What can a database compiled over 22 years tell us about the use of different types of wetlands by waterfowl in southeastern Australian summers? Emu 112:209-217. https://doi.org/10.1071/MU11070

31. Murray CG, Kasel S, Szantyr E, Barratt R, Hamilton AJ (2014) Waterbird use of different treatment stages in waste-stabilisation pond systems. Emu 114: 30-40. https://doi.org/10.1071/MU12121 
32. Nixon SW, Buckley BA, Granger SL, Entsua-Mensah M, Ansa-Asare O, White MJ, McKinney RA, Mensah E (2007) Anthropogenic enrichment and nutrients in some tropical lagoons of Ghana, West Africa. Ecol Appl 17(5) Supplement:S144-S164. https://doi.org/10.1890/05-0684.1

33. Ntiamoa-Baidu Y (1991) Seasonal changes in the importance of coastal wetlands in Ghana for wading birds. Biol Conserv 57(2):139-158. https://doi.org/10.1016/0006-3207(91)90135-V

34. Ntiamoa-Baidu Y, Piersma T, Wiersma P, Poot M, Battley P, Gordon C (1998) Habitat selection, daily foraging routines and diet of waterbirds in coastal lagoons in Ghana. Ibis 140:89-103. https://doi.org/10.1111/j.1474-919X.1998.tb04545.x

35. O'Connell M (2000) Threats to waterbirds and wetlands: Implications for conservation, inventory and research. Wildfowl 51:1-15. https://wildfowl.wwt.org.uk/index.php/wildfowl/article/view/1076

36. Okes NC, Hockey PAR, Cumming GS (2008) Habitat use and life history as predictors of bird responses to habitat change. Conserv Biol 22(1):151-162. https://doi.org/10.1111/j.15231739.2007.00862.x

37. Otieno NE, Mutati AS, Akoth C, Ogwanjg D, Mwinami T, Alaro P, Njoka J (2015) Role of invertebrate prey abundance on waterbird distribution across rice field growth stages in Western Kenya. Waterbirds 38(1):47-57. https://doi.org/10.1675/063.038.0107

38. Runge CA, Watson JEM, Butchart SHM, Hanson JO, Possingham HP, Fuller RA (2015) Protected areas and global conservation of migratory birds. Science 350 (6265):1255-1258. https://doi.org/10.1126/science.aac9180

39. Scholz M, Lee B-h (2005) Constructed wetlands: a review. Internat J Environm Stud 62(4):421-447. https://doi.org/10.1080/00207230500119783

40. Santoul F, Mastrorillo S (2004) Gravel pits as new wetlands for the Little Grebe Tachybaptus ruficollis. Vie Milieu 54(1):31-36.

41. Schuyt KD (2005) Economic consequences of wetland degradation for local populations in Africa. Ecol Econom 53:177-190. https://doi.org/10.1016/j.ecolecon.2004.08.003

42. Sutherland WJ, Alves JA, Amano T, Chang CH, Davidson NC, Max Finlayson C, Gill JA, Gill RE, González PM, Gunnarsson TG, Kleijn D, Spray CJ, Székely T, Thompson DBA (2012) A horizon scanning assessment of current and potential future threats to migratory shorebirds. Ibis 154:663679. https://doi.org/10.1111/j.1474-919X.2012.01261.x

43. Uluocha NO, Okeke IC (2004) Implications of wetlands degradation for water resources management: Lessons from Nigeria. GeoJournal 61:151-154. https://doi.org/10.1007/s10708-004-2868-3

44. Verhoeven JTA, Arheimer B, Yin C, Hefting MM (2006) Regional and global concerns over wetlands and water quality. Trends Ecol Evol 21(2):96-103. https://doi.org/10.1016/j.tree.2005.11.015

45. Vickery JA, Ewing SR, Smith KW, Pain DJ, Bairlein F, Škorpilová J, Gregory RD, Fox T (2014) The decline of Afro-Palaearctic migrants and an assessment of potential causes. Ibis 156:1-22. https://doi.org/10.1111/ibi.12118

46. Wang H, Wang T, Zhang B, Li F, Toure B, Omosa IB, Chiramba T, Abdel-Monem M, Pradhan M (2014) Water and wastewater treatment in Africa - current practices and challenges. Clean Soil Air Water 
42:1029-1035. https://doi.org/10.1002/clen.201300208

47. Wang R, Wu F, Chang Y, Yang X (2016) Waterbirds and their habitat utilization of artificial wetlands at Dianchi Lake: implication for waterbird conservation in Yunnan-Guizhou Plateau Lakes. Wetlands 36:1087-1095. https://doi.org/10.1007/s13157-016-0823-y

48. Willoughby N, Grimble R, Ellenbroek E, Danso E, Amatekpor J (2001) The wise use of wetlands: identifying development options for Ghana's coastal Ramsar sites. Hydrobiologia 458:221-234. https://doi.org/10.1023/A:1013158329107

49. Wymenga E, Zwarts L (2010) Use of rice fields by birds in West Africa. Waterbirds 33 (Special Publication 1):97-104. https://doi.org/10.1675/063.033.s107

\section{Tables}


Table 1

Total number of species, species diversity and accumulated number of birds counted during nine counts $\left(N_{\text {month }}\right)$ in each month of November 2013 - January 2014, at the Legon Sewage Treatment Plant, Accra $\left(N_{\text {total }}=27\right)$. Numbers in brackets represent the mean abundance \pm SD across the three pond replicates $(1-3)$ for each level (A-D).

\begin{tabular}{|c|c|c|c|c|c|c|c|c|c|}
\hline \multicolumn{2}{|l|}{ Species } & \multirow{2}{*}{$\begin{array}{l}\text { Forag. } \\
\text { guild }^{2}\end{array}$} & \multicolumn{2}{|l|}{ Status } & \multicolumn{4}{|c|}{ Pond level ${ }^{5}$} & \multirow{2}{*}{$\begin{array}{l}\text { All } \\
\text { ponds }\end{array}$} \\
\hline $\begin{array}{l}\text { English } \\
\text { name }^{1}\end{array}$ & $\begin{array}{l}\text { Scientific } \\
\text { name }^{1}\end{array}$ & & Local $^{3}$ & IUCN $^{4}$ & A & B & C & D & \\
\hline $\begin{array}{l}\text { White-faced } \\
\text { whistling } \\
\text { duck }\end{array}$ & $\begin{array}{l}\text { Dendrocygna } \\
\text { viduata }\end{array}$ & 1 & RB & LC & - & $\begin{array}{l}20 \\
(7 \pm \\
10)\end{array}$ & $\begin{array}{l}564 \\
(188 \\
\pm 31)\end{array}$ & $\begin{array}{l}275 \\
(92 \\
\pm \\
106)\end{array}$ & $\begin{array}{l}859 \\
(286 \\
\pm \\
116)\end{array}$ \\
\hline $\begin{array}{l}\text { Knob-billed } \\
\text { duck }\end{array}$ & $\begin{array}{l}\text { Sarkidiornis } \\
\text { melanotos }\end{array}$ & 1 & A & LC & - & $\begin{array}{l}1(0 \\
\pm 1)\end{array}$ & - & - & $\begin{array}{l}1(0 \pm \\
1)\end{array}$ \\
\hline $\begin{array}{l}\text { Common } \\
\text { moorhen }\end{array}$ & $\begin{array}{l}\text { Gallinula } \\
\text { chloropus }\end{array}$ & 1 & RB & LC & - & - & $\begin{array}{l}17 \\
(6 \pm \\
6)\end{array}$ & $\begin{array}{l}14 \\
(5 \pm \\
2)\end{array}$ & $\begin{array}{l}31 \\
(10 \pm \\
6)\end{array}$ \\
\hline $\begin{array}{l}\text { Senegal } \\
\text { thick-knee }\end{array}$ & $\begin{array}{l}\text { Burhinus } \\
\text { senegalensis }\end{array}$ & 2 & A/RB & LC & - & $\begin{array}{l}110 \\
(37 \\
\pm 24)\end{array}$ & - & $\begin{array}{l}20 \\
(7 \pm \\
12)\end{array}$ & $\begin{array}{l}130 \\
(43 \pm \\
35)\end{array}$ \\
\hline $\begin{array}{l}\text { Common } \\
\text { ringed } \\
\text { plover }\end{array}$ & $\begin{array}{l}\text { Charadrius } \\
\text { hiaticula }\end{array}$ & 2 & $P$ & LC & $\begin{array}{l}6(2 \\
\pm 2)\end{array}$ & $\begin{array}{l}6(2 \\
\pm 4)\end{array}$ & $\begin{array}{l}1(0 \\
\pm 1)\end{array}$ & - & $\begin{array}{l}13(4 \\
\pm 2)\end{array}$ \\
\hline $\begin{array}{l}\text { Spur-winged } \\
\text { lapwing }\end{array}$ & $\begin{array}{l}\text { Vanellus } \\
\text { spinosus }\end{array}$ & 2 & $\mathrm{RB}$ & LC & $\begin{array}{l}53 \\
(18 \\
\pm 1)\end{array}$ & $\begin{array}{l}66 \\
(22 \\
\pm 7)\end{array}$ & $\begin{array}{l}64 \\
(21 \\
\pm 1)\end{array}$ & $\begin{array}{l}105 \\
(35 \\
\pm 6)\end{array}$ & $\begin{array}{l}288 \\
(96 \pm \\
11)\end{array}$ \\
\hline $\begin{array}{l}\text { African } \\
\text { wattled } \\
\text { lapwing }\end{array}$ & $\begin{array}{l}\text { Vanellus } \\
\text { senegallus }\end{array}$ & 2 & $\mathrm{RB}$ & LC & - & - & - & $\begin{array}{l}64 \\
(21 \\
\pm 12)\end{array}$ & $\begin{array}{l}64 \\
(21 \pm \\
12)\end{array}$ \\
\hline $\begin{array}{l}\text { African } \\
\text { jacana }\end{array}$ & $\begin{array}{l}\text { Actophilornis } \\
\text { africanus }\end{array}$ & 2 & $\mathrm{RB}$ & LC & - & $\begin{array}{l}4(1 \\
\pm 2)\end{array}$ & $\begin{array}{l}35 \\
(12 \\
\pm 3)\end{array}$ & $\begin{array}{l}5(2 \\
\pm 3)\end{array}$ & $\begin{array}{l}44 \\
(15 \pm \\
8)\end{array}$ \\
\hline $\begin{array}{l}\text { Common } \\
\text { snipe }\end{array}$ & $\begin{array}{l}\text { Gallinago } \\
\text { gallinago }\end{array}$ & 2 & $P$ & LC & - & $\begin{array}{l}1(0 \\
\pm 1)\end{array}$ & - & - & $\begin{array}{l}1(0 \pm \\
1)\end{array}$ \\
\hline $\begin{array}{l}\text { Common } \\
\text { sandpiper }\end{array}$ & $\begin{array}{l}\text { Actitis } \\
\text { hypoleucos }\end{array}$ & 2 & $P$ & LC & $\begin{array}{l}93 \\
(31 \\
\pm \\
16)\end{array}$ & $\begin{array}{l}419 \\
(140 \\
\pm 57)\end{array}$ & $\begin{array}{l}57 \\
(19 \\
\pm 14)\end{array}$ & $\begin{array}{l}37 \\
(12 \\
\pm 8)\end{array}$ & $\begin{array}{l}606 \\
(202 \\
\pm 27)\end{array}$ \\
\hline $\begin{array}{l}\text { Wood } \\
\text { sandpiper }\end{array}$ & $\begin{array}{l}\text { Tringa } \\
\text { glareola }\end{array}$ & 2 & $P$ & LC & $\begin{array}{l}41 \\
(14 \\
\pm 5)\end{array}$ & $\begin{array}{l}314 \\
(105 \\
\pm 27)\end{array}$ & $\begin{array}{l}84 \\
(28 \\
\pm 20)\end{array}$ & $\begin{array}{l}41 \\
(14 \\
\pm 10)\end{array}$ & $\begin{array}{l}480 \\
(160 \\
\pm 37)\end{array}$ \\
\hline
\end{tabular}




\begin{tabular}{|c|c|c|c|c|c|c|c|c|c|}
\hline \multicolumn{2}{|l|}{ Species } & \multirow{2}{*}{$\begin{array}{l}\text { Forag. } \\
\text { guild }^{2}\end{array}$} & \multicolumn{2}{|l|}{ Status } & \multicolumn{4}{|c|}{ Pond level ${ }^{5}$} & \multirow{2}{*}{$\begin{array}{l}\text { All } \\
\text { ponds }\end{array}$} \\
\hline $\begin{array}{l}\text { English } \\
\text { name }^{1}\end{array}$ & $\begin{array}{l}\text { Scientific } \\
\text { name }^{1}\end{array}$ & & Local $^{3}$ & IUCN 4 & A & B & C & D & \\
\hline $\begin{array}{l}\text { Common } \\
\text { redshank }\end{array}$ & $\begin{array}{l}\text { Tringa } \\
\text { totanus }\end{array}$ & 2 & $P$ & LC & - & $\begin{array}{l}1(0 \\
\pm 1)\end{array}$ & - & - & $\begin{array}{l}1(0 \pm \\
1)\end{array}$ \\
\hline Little stint & $\begin{array}{l}\text { Calidris } \\
\text { minuta }\end{array}$ & 3 & $P$ & LC & $\begin{array}{l}1(0 \\
\pm 1)\end{array}$ & $\begin{array}{l}1(0 \\
\pm 1)\end{array}$ & - & - & $\begin{array}{l}1(1 \pm \\
1)\end{array}$ \\
\hline $\begin{array}{l}\text { Black- } \\
\text { winged stilt }\end{array}$ & $\begin{array}{l}\text { Himantopus } \\
\text { himantopus }\end{array}$ & 4 & $\mathrm{RB} / \mathrm{P} ?$ & LC & $\begin{array}{l}91 \\
(30 \\
\pm \\
24)\end{array}$ & $\begin{array}{l}205 \\
(68 \\
\pm 41)\end{array}$ & $\begin{array}{l}192 \\
(64 \\
\pm 40)\end{array}$ & $\begin{array}{l}46 \\
(15 \\
\pm 6)\end{array}$ & $\begin{array}{l}534 \\
(178 \\
\pm 32)\end{array}$ \\
\hline $\begin{array}{l}\text { Common } \\
\text { greenshank }\end{array}$ & $\begin{array}{l}\text { Tringa } \\
\text { nebularia }\end{array}$ & 4 & $P$ & LC & $\begin{array}{l}1(0 \\
\pm 1)\end{array}$ & $\begin{array}{l}68 \\
(23 \\
\pm 7)\end{array}$ & $\begin{array}{l}49 \\
(16 \\
\pm 20)\end{array}$ & $\begin{array}{l}18 \\
(6 \pm \\
7)\end{array}$ & $\begin{array}{l}136 \\
(45 \pm \\
24)\end{array}$ \\
\hline $\begin{array}{l}\text { Green- } \\
\text { backed } \\
\text { heron }\end{array}$ & $\begin{array}{l}\text { Butorides } \\
\text { striata }\end{array}$ & 5 & RB & LC & - & - & $\begin{array}{l}8(3 \\
\pm 2)\end{array}$ & $\begin{array}{l}2(1 \\
\pm 1)\end{array}$ & $\begin{array}{l}10(3 \\
\pm 2)\end{array}$ \\
\hline $\begin{array}{l}\text { Squacco } \\
\text { heron }\end{array}$ & $\begin{array}{l}\text { Ardeola } \\
\text { ralloides }\end{array}$ & 5 & $P$ & LC & - & $\begin{array}{l}4(1 \\
\pm 2)\end{array}$ & $\begin{array}{l}23 \\
(8 \pm \\
6)\end{array}$ & $\begin{array}{l}6(2 \\
\pm 3)\end{array}$ & $\begin{array}{l}33 \\
(11 \pm \\
10)\end{array}$ \\
\hline Cattle egret & $\begin{array}{l}\text { Bubulcus } \\
\text { ibis }\end{array}$ & 5 & $\mathrm{~A} / \mathrm{RB}$ & LC & - & $\begin{array}{l}39 \\
(13 \\
\pm 15)\end{array}$ & $\begin{array}{l}114 \\
(38 \\
\pm 25)\end{array}$ & $\begin{array}{l}571 \\
(190 \\
\pm 24)\end{array}$ & $\begin{array}{l}724 \\
(241 \\
\pm 44)\end{array}$ \\
\hline Grey heron & $\begin{array}{l}\text { Ardea } \\
\text { cinerea }\end{array}$ & 5 & $\mathrm{P} / \mathrm{RB}$ & LC & - & $\begin{array}{l}2(1 \\
\pm 1)\end{array}$ & $\begin{array}{l}11 \\
(4 \pm \\
1)\end{array}$ & $\begin{array}{l}9(3 \\
\pm 2)\end{array}$ & $\begin{array}{l}22(7 \\
\pm 3)\end{array}$ \\
\hline $\begin{array}{l}\text { Intermediate } \\
\text { egret }\end{array}$ & $\begin{array}{l}\text { Ardea } \\
\text { intermedia }\end{array}$ & 5 & $\mathrm{~A} / \mathrm{RB} ?$ & LC & - & $\begin{array}{l}1(0 \\
\pm 1)\end{array}$ & $\begin{array}{l}16 \\
(5 \pm \\
3)\end{array}$ & $\begin{array}{l}7(2 \\
\pm 2)\end{array}$ & $\begin{array}{l}24(8 \\
\pm 5)\end{array}$ \\
\hline Black heron & $\begin{array}{l}\text { Egretta } \\
\text { ardesiaca }\end{array}$ & 5 & $\mathrm{RB}$ & LC & - & - & $\begin{array}{l}6(2 \\
\pm 2)\end{array}$ & $\begin{array}{l}7(2 \\
\pm 3)\end{array}$ & $\begin{array}{l}13(4 \\
\pm 4)\end{array}$ \\
\hline Little egret & $\begin{array}{l}\text { Egretta } \\
\text { garzetta }\end{array}$ & 5 & P/RB? & LC & - & - & $\begin{array}{l}13(4 \\
\pm 4)\end{array}$ & $\begin{array}{l}2(1 \\
\pm 1)\end{array}$ & $\begin{array}{l}15(5 \\
\pm 4)\end{array}$ \\
\hline $\begin{array}{l}\text { Western reef } \\
\text { egret }\end{array}$ & $\begin{array}{l}\text { Egretta } \\
\text { gularis }\end{array}$ & 5 & $\mathrm{RB}$ & LC & - & - & $\begin{array}{l}7(2 \\
\pm 1)\end{array}$ & - & $\begin{array}{l}7(2 \pm \\
1)\end{array}$ \\
\hline Little grebe & $\begin{array}{l}\text { Tachybaptus } \\
\text { ruficollis }\end{array}$ & 6 & $\mathrm{RB}$ & LC & - & $\begin{array}{l}4(1 \\
\pm 2)\end{array}$ & $\begin{array}{l}57 \\
(19 \\
\pm 4)\end{array}$ & $\begin{array}{l}99 \\
(33 \\
\pm 5)\end{array}$ & $\begin{array}{l}160 \\
(53 \pm \\
2)\end{array}$ \\
\hline $\begin{array}{l}\text { Long-tailed } \\
\text { cormorant }\end{array}$ & $\begin{array}{l}\text { Microcarbo } \\
\text { africanus }\end{array}$ & 6 & RB & LC & - & - & $\begin{array}{l}22 \\
(7 \pm \\
13)\end{array}$ & - & $\begin{array}{l}22(7 \\
\pm 13)\end{array}$ \\
\hline
\end{tabular}




\begin{tabular}{|c|c|c|c|c|c|c|c|c|c|}
\hline \multicolumn{2}{|l|}{ Species } & \multirow{2}{*}{$\begin{array}{l}\text { Forag. } \\
\text { guild }^{2}\end{array}$} & \multicolumn{2}{|l|}{ Status } & \multicolumn{4}{|c|}{ Pond level ${ }^{5}$} & \multirow{2}{*}{$\begin{array}{l}\text { All } \\
\text { ponds }\end{array}$} \\
\hline $\begin{array}{l}\text { English } \\
\text { name }^{1}\end{array}$ & $\begin{array}{l}\text { Scientific } \\
\text { name }^{1}\end{array}$ & & Local $^{3}$ & IUCN $^{4}$ & A & B & $\mathrm{C}$ & D & \\
\hline $\begin{array}{l}\text { Malachite } \\
\text { kingfisher }\end{array}$ & $\begin{array}{l}\text { Corythornis } \\
\text { cristatus }\end{array}$ & 6 & RB & LC & - & $\begin{array}{l}1(0 \\
\pm 1)\end{array}$ & $\begin{array}{l}1(0 \\
\pm 1)\end{array}$ & $\begin{array}{l}2(1 \\
\pm 1)\end{array}$ & $\begin{array}{l}4(1 \pm \\
1)\end{array}$ \\
\hline \multicolumn{5}{|c|}{$\begin{array}{l}\text { Total accumulated abundance of } 27 \text { daily counts ( } 9 \\
\text { counts per month) }\end{array}$} & $\begin{array}{l}286 \\
(95 \\
\pm \\
19)\end{array}$ & $\begin{array}{l}1267 \\
(422 \\
\pm \\
133)\end{array}$ & $\begin{array}{l}1341 \\
(447 \\
\pm 97)\end{array}$ & $\begin{array}{l}1330 \\
(443 \\
\pm \\
136)\end{array}$ & $\begin{array}{l}4224 \\
(1408 \\
\pm \\
222)\end{array}$ \\
\hline \multicolumn{5}{|c|}{ Species richness (S) } & 7 & 19 & 20 & 19 & 26 \\
\hline \multicolumn{5}{|c|}{ Species diversity (ExpH') } & 4.23 & 6.21 & 7.58 & 6.59 & 10.01 \\
\hline
\end{tabular}

1,3 Dowsett-Lemaire \& Dowsett (2014): RB = Resident breeding; $P$ = Palaearctic migrant; A = African migrant; ${ }^{2}$ Ntiamoa-Baidu et al. (1998); ${ }^{4}$ LC = Least concern;

${ }^{5} \mathrm{~A}=$ anaerobic $(5 \mathrm{~m}), \mathrm{B}=$ aerobic facultative $(2.5 \mathrm{~m}), \mathrm{C}$ and $\mathrm{D}=$ aerobic maturation $(1.3 \mathrm{~m})$.

Table 2

Species similarity $\left(\mathrm{C}_{\mathrm{H}}\right)$ among the four

levels A-D, during November 2013 to January 2014 at the LSTP, Accra.

\begin{tabular}{|lllll|}
\hline Level & A & B & C & D \\
\hline A & & 0.863 & 0.322 & 0.154 \\
\hline B & & & 0.311 & 0.199 \\
C & & & & 0.603 \\
\hline D & & & & \\
\hline
\end{tabular}


Table 3

Total waterbird abundance distributed on foraging guilds (1-6), ecological diversity (ExpH') across all foraging guilds, and physico-chemical parameters for each pond level (A-D) and all ponds combined, during November 2013 to January 2014 at the LSTP, Accra. Numbers in brackets are \% of all 4224 birds counted or \% of all 26 species observed.

\begin{tabular}{|llllll|}
\hline Foraging guild & \multicolumn{2}{l}{ Pond Level $(\mathbf{n}=\mathbf{3})$} & & $\begin{array}{l}\text { All ponds } \\
(\mathbf{n}=12)\end{array}$ \\
\cline { 2 - 6 } & A & B & C & D & \\
\hline 1 & - & $21(0.5)$ & $581(13.8)$ & $289(6.8)$ & $891(21.1)$ \\
\hline 2 & $193(4.6)$ & $921(21.8)$ & $241(5.7)$ & $272(6.4)$ & $1627(38.5)$ \\
\hline 3 & $1(<0.1)$ & $1(<0.1)$ & - & - & $2(<0.1)$ \\
\hline 4 & $92(2.2)$ & $273(6.5)$ & $241(5.7)$ & $64(1.5)$ & $670(15.9)$ \\
\hline 5 & - & $46(1.1)$ & $198(4.7)$ & $604(14.3)$ & $848(20.1)$ \\
\hline 6 & - & $5(0.1)$ & $80(1.9)$ & $101(2.4)$ & $186(4.4)$ \\
\hline Total N (\%) & $286(6.8)$ & $1267(30.0)$ & $1341(31.7)$ & $1330(31.5)$ & $4224(100.0)$ \\
\hline Total S (\%) & $7(26.9)$ & $19(73.1)$ & $20(76.9)$ & $19(73.1)$ & $26(100.0)$ \\
\hline Exp(H') & 1.92 & 2.18 & 4.18 & 3.88 & 4.27 \\
\hline pH & $7.9 \pm 0.1$ & $8.8 \pm 0.2$ & $10.6 \pm 0.1$ & $8.8 \pm 0.4$ & $9.1 \pm 1.0$ \\
\hline TDO (mg/l) & $9.7 \pm 7.8$ & $16.1 \pm 3.1$ & $24.7 \pm 1.5$ & $8.5 \pm 3.2$ & $14.7 \pm 7.7$ \\
\hline Turbidity (NTU) & $301.3 \pm 11.5$ & $358.3 \pm 25.2$ & $369.0 \pm 83.2$ & $18.0 \pm 0.9$ & $261.7 \pm 154.0$ \\
\hline Water depth (m) & 5.0 & 2.5 & 1.3 & 1.3 & - \\
\hline
\end{tabular}

11 = Herbivorous waterfowl (ducks/moorhens), 2 = Visual surface foraging waders, 3 = Tactile surface foraging waders,

4 = Pelagic foraging waders, 5 = Stalking herons, 6 = Diving piscivorous birds (waterfowl $/$ kingfishers).

\section{Figures}



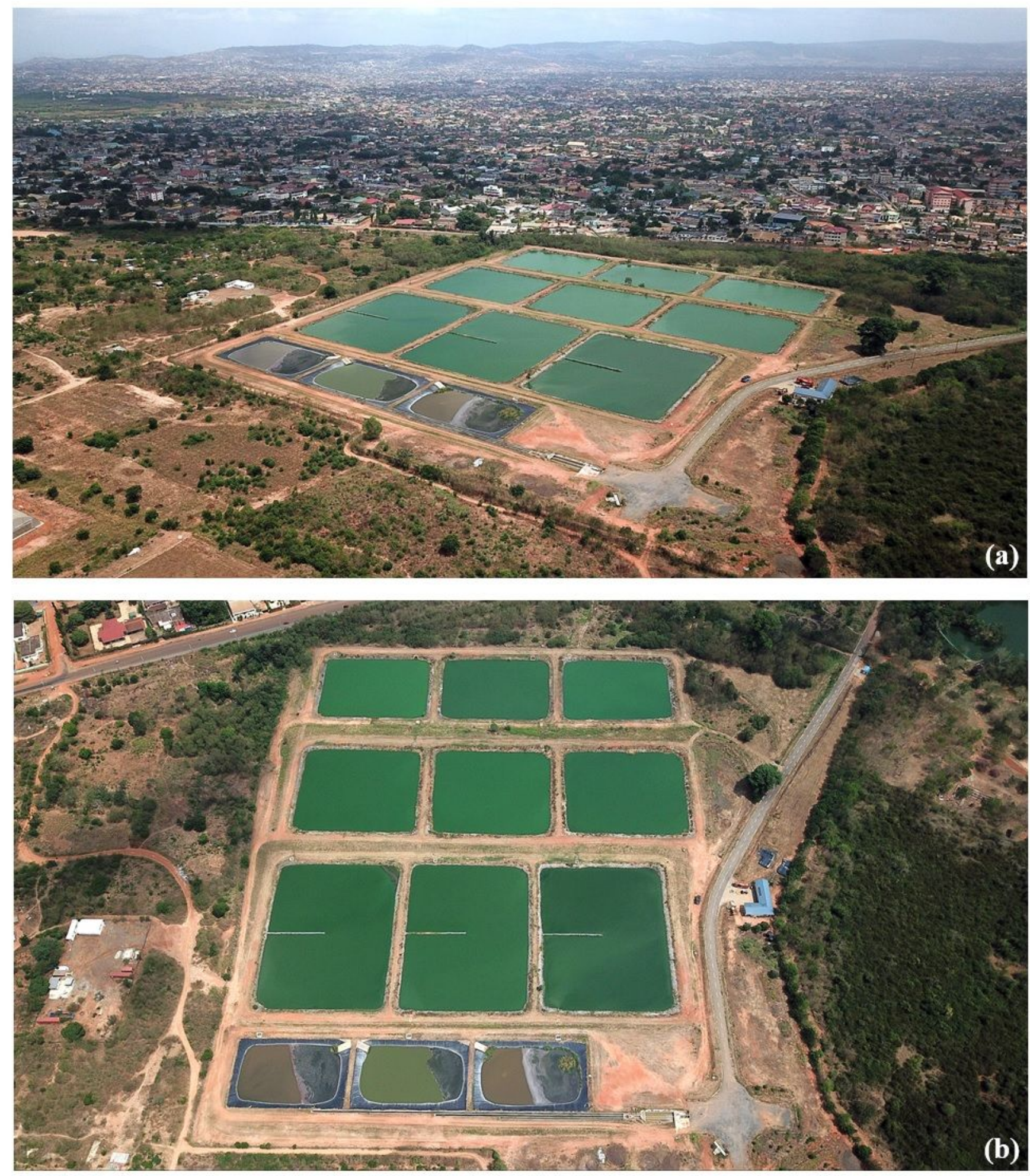

\section{Figure 1}

(a) Aerial view of the Legon Sewage Treatment Plant (LSTP), with the surrounding urban areas and the Legon Botanical Gardens to the East; (b) Perpendicular perspective of the LSTP; images taken with a drone (DJI Mavic Pro®). 


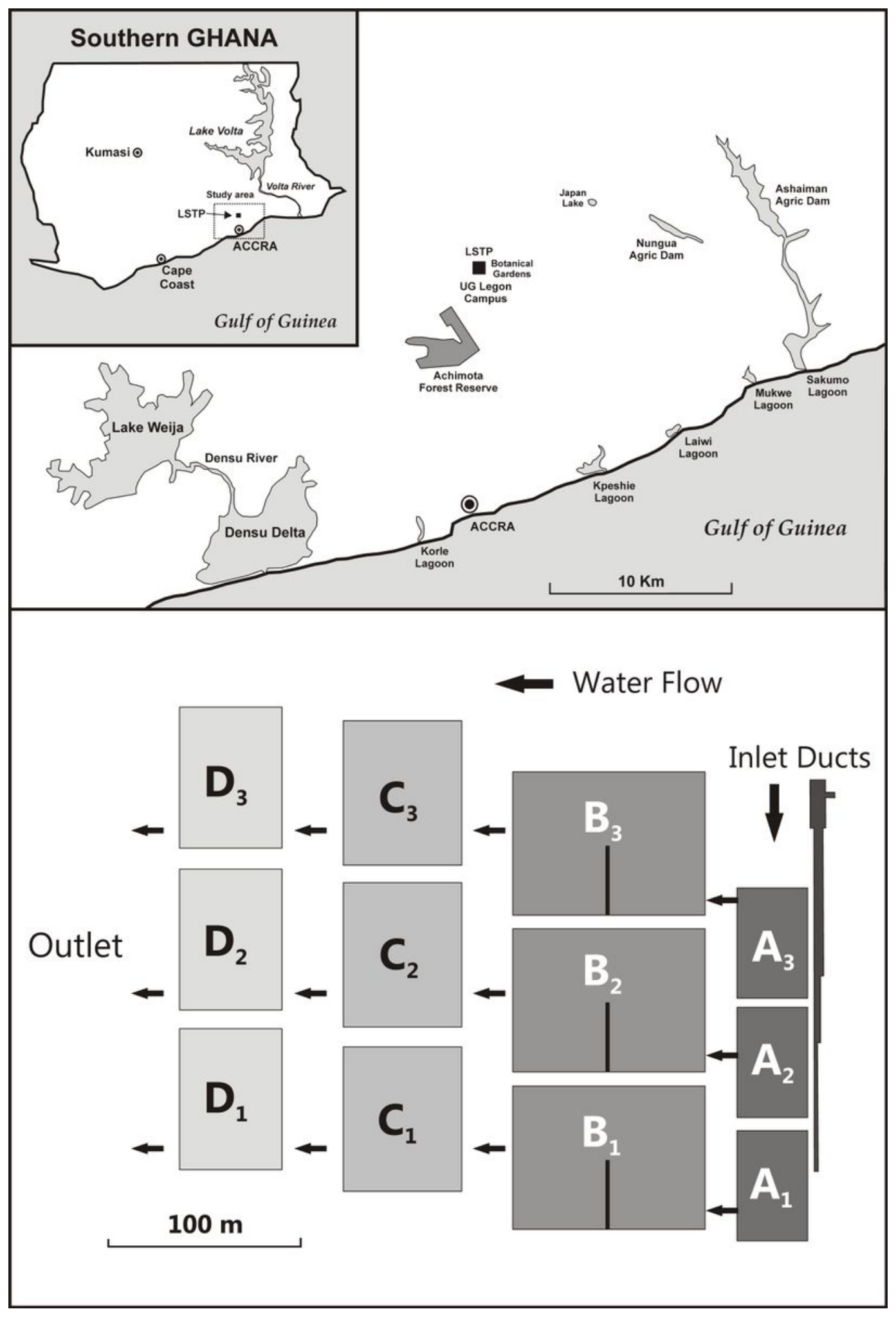

\section{Figure 2}

Map showing the position of the Legon Sewage Treatment Plant (LSTP), with surrounding coastal and inland wetlands within the Accra Plains (top), Southern Ghana (insert). LSTP only drawn approximately to scale (bottom). Note: The designations employed and the presentation of the material on this map do not imply the expression of any opinion whatsoever on the part of Research Square concerning the legal 
status of any country, territory, city or area or of its authorities, or concerning the delimitation of its frontiers or boundaries. This map has been provided by the authors. 